\title{
THE GAS UTILITIES ACT AND THE PRACTICE, PROCEDURE AND JURISDICTION OF THE ALBERTA PUBLIC UTILITIES BOARD
}

\author{
J. C. CRAWFORD*
}

\begin{abstract}
After reviewing the provisions of the Alberta Gas Utilities Act, particularly the recent amendments thereto, the author submits inter alia, that the Alberta Public Utilities Board, despite s. 28(2) of the Public Utilities Board Act and s. 27 of the Gas Utilities Act, may not have the power to set producer or wholesale prices of natural gas, propane and butane where these products are not intended for use and consumption within the province, because such regulation is a matter for the Federal Government pursuant to its jurisdiction over extra-provincial trade. As well, the author examines generally the practice, procedure and jurisdiction of the Alberta Public Utilities Board.
\end{abstract}

Section 4 of The Gas Utilities Act ${ }^{1}$ provides, inter alia, that the Act will apply to all gas utilities owned or operated by or under the control of a company that is subject to the legislative authority of the Province or, by virtue of an agreement with the municipality, has submitted to.the jurisdiction and control of the Board and to every person owning or operating a gas utility to which the jurisdiction of the province extends. The Board is defined by Section 2(b) to be The Public Utilities Board as constituted pursuant to The Public Utilities Board Act. ${ }^{2}$

This Board presently has offices in the Petroleum Plaza in Edmonton and at No. 510, Aquitaine Tower, 540 - 5th Avenue South West in Calgary. The Board members are Mr. Miles H. Patterson, Q.C., Chairman; Mr. W. D. Abercrombie, Vice-Chairman; and Messrs. H. A. Williams, B. O. Archibald and W. R. Horton, Members; and Messrs. J. C. Saks, F. Trofanenko and G. F. Coote, Acting Members. Practitioners dealing with the Board have most occasion to deal with Mr. C. R. Leishman as Director of Hearings and the Board Secretary in Edmonton, and Mr. T. Oystrick as the Assistant Director of Hearings and Office Manager in Calgary.

On June 6th, 1974, assent was given to the Natural Gas Rebates Act. Applications for a rebate under this Act are made to the Director of Rebates, a position established under the Statute. However, The Public Utilities Board also has an involvement under this Statute in that it must issue two certificates prior to a rebate being granted under this Act. Firstly, the Board must certify that the price for the gas on which the rebate is being paid is just and reasonable. Secondly, the Board must issue a certificate stating that the full benefit of the rebate being paid is to be passed on to the ultimate consumer. As a result of this legislation the Board must now scrutinize gas supply contracts in order to be in a position to issue these certificates. Thus, if you are dealing with a gas contract involving an Alberta "gas utility" then you should consider the implications of this legislation.

\footnotetext{
- Barrister and Solicitor, General Counsel, Canadian Industrial Gas \& Oil Ltd., Calgary, Alberta.

S.A. 1960, c. 37.

2 S.A. 1960 , c. 85.
} 
The Gas Utilities Act was amended in late $1973^{3}$ in order to place all distributors of butane and propane for use, retention or consumption in Alberta under the jurisdiction of the Board. This aspect of the Board's jurisdiction will be discussed at some length later in this paper.

Section 2(f) defines a gas utility to mean, inter alia, any gas pipe line, any system, works, pipes, equipment or service for the production, gathering, conveying, transmission, transporting, delivery, furnishing, or supplying of gas by retail or wholesale, either directly or indirectly, to or for the public or any member of the public whether an individual or a corporation; any absorption or scrubbing plant; and any system, well works, plant equipment or service for the production of gas or capable of producing gas which may be declared by the Energy Resources Conservation Board to be a gas utility.

Even in the absence of the aforesaid declaration by the Energy Resources Conservation Board, this definition may be interpreted by The Public Utilities Board as including even the owner of a capped gas well who does not seek to sell gas for use or consumption within Alberta. Thus, companies who consider themselves to be strictly in the exploration phase of the oil and gas business are theoretically a gas utility. Unless such companies make application pursuant to Section 3 of The Gas Utilities Act for a declaration exempting them from certain sections of the Act, this can have rather horrendous implications for such companies. A perusal of Section 24 will soon convince any but the most complacent of the efficacy of this statement.

In 1974 the Board instituted a practice of holding "in office" hearings at the Board's offices in both Edmonton and Calgary. Thursday morning is usually the time when such applications may be heard at the Calgary office of the Board. The current guidelines governing the form of such application for a declaration exempting a company from certain sections of the Act are available from the Board. I would recommend that any gas exploration and production companies operating in Alberta and not having such an exemption should make application at the earliest opportunity. At the very least, such companies would appear to be in violation of the rate base accounting requirements of Section 28 .

The Board publishes a set of procedural rules. However, it may be fairly said that public hearings are usually held without any undue reliance on these rules and the overriding concern of the Chairman or Acting Chairman would seem to be for the rules of natural justice so that every person having an interest in the proceedings, however remote, may have an opportunity to present his views to the Board. The Board sits with at least three members except on the Thursday morning "advice and direction" hearings when one or two members will sit and take a report to the afternoon "full panel" in camera sitting of the Board which will then hand down any decision required. The Board's proceedings are also subject to the Administrative Procedures Act.

The Board had occasion to comment on the principles which govern the award of costs in relation to public rate applications in its Decision No. 30202 dated March 29, 1971. Copies of Board decisions are usually available at either of the Board's offices.

Notwithstanding the above, I would submit that the Board may not 
have the power to set producer or wholesale prices of natural gas, propane and butane where these products are not intended for use and consumption within the Province. ${ }^{4}$ The Board of course is a creature of statute and it only has the powers which may be validly conferred by an intra vires Act of the Legislature of Alberta. ${ }^{5}$ It is well settled that a Province cannot purport to control extra-provincial trade as an adjunct of -intra-provincial trade. ${ }^{6}$

The Gas Utilities Act was amended, effective March 6, 1974, to give the Board power to set prices on products of absorption plants (i.e. propane) and all wholesale and retail prices of such products were otherwise frozen as of that date. It is submitted that subsection 28(2) of The Public Utilities Board Act and Section 27 of The Gas Utilities Act may not validly confer such a jurisdiction on the Board because it is doubtful whether such an enactment is intra vires of the Provincial Legislature of Alberta.

While the Province is empowered to deal with "Property and Civil Rights in the Province" and "Generally all Matters of a merely local or private Nature in the Province" pursuant to Sections 92(13) and 92(16) respectively of The British North America Act, ${ }^{7}$ the Federal Government, under Section 91(2) of that Act is empowered to exclusively make laws in relation to "The Regulation of Trade and Commerce". While the Courts have held that the Federal Parliament is not empowered under 91(2) to regulate a particular trade that is carried on wholly within a Province (eg. licencing of insurance salesmen) ${ }^{8}$ and is purely local in its nature, it is doubtful that the regulation of the wholesale price of propane in Alberta, where $85 \%$ of production is destined for extra-provincial and foreign markets, is such a local trade. ${ }^{9}$

The so-called "chicken and egg war" conflict illustrates the futility of one province trying to regulate prices on a commodity to the exclusion of users and suppliers outside that province. We would submit that once a commodity enters the stream of commerce (i.e. is severed from its resource or manufacturing base) then Section 92(5) and Section 109 would not apply. It would then, we suggest, be in "pith and substance" a matter of Trade and Commerce within the meaning of the said Section 91(2) of the B.N.A. Act, especially where there is a substantial extraprovincial aspect to the trade in that commodity.

The Federal Parliament could also declare that absorption plants were "works and undertakings" for the general advantage of Canada under Section 92(10)(c) of the B.N.A. Act, as was done with all grain elevators in Western Canada. This is how the Federal Government initially extended its jurisdiction to cover the grain trade. ${ }^{10}$

- See Section 6.

3 See Section 28 of the Public Utilities Board Act, S.A. 1960, c. 85 and Section 27 of The Gas Utilities Act, S.A. 1960 , c. 37.

- See Pigeon J. at p. 544 of Burns Foods Ltd. et al. v. The Attorney General of Manitoba [1974] 2 W.W.R. 537.

730 \& 31 , Victoria c. 3.

- See Duff C.J. at p. 410 in Reference re The Natural Products Marketing Act, 1934, [1936] S.C.R. 384. Affirmed sub nom Attorney General of British Columbia v. Attorney General of Canada [1937] A.C. 368. Also Citizens Insurance Co. v. Parsons (1881) 7 A.C. 96.

- See Judgment of Laskin J. and Hall J. in Attorney General of Manitoba v. Manitoba Egg \& Poultry Association [1971] S.C.R. 689.

10 Canada Grain Act, R.S.C. 1970, c. G-16, s. 174. But see also Murphy v. C.P.R. and Attorney. General of Canada [1958] S.C.R. 626 where 91(2) was relied upon to support Canadian Wheat Board regulations. 
We would submit that because the Board is now attempting to regulate propane prices, the Federal authorities will now step in to regulate the industry pursuant to Bill $\mathrm{C} 32 .{ }^{.1}$ We submit further that such regulation is not in the Canadian public interest, and most especially not in the Alberta public interest. Alberta consumers may well lose the preference as to price and supply which they presently enjoy, and may in the future pay substantially higher prices as a result.

It is submitted that a business must be either local in nature or a de facto common law public utility (which would in itself make it local in nature) before the legislature and any regulatory body established under its delegated legislation, could validly regulate the business. When a business is juris privati it is not clothed with the "public interest" and it is therefore not in fact a "public utility". It is usually only where a business or undertaking is invested with a monopoly of a public privilege that it can be said to be clothed with the public interest. ${ }^{12}$

Part I of the Act ${ }^{13}$ deals with Gas Prices (formerly "Field Prices of Gas"). Mindful of the problems of the U.S. Federal Power Commission that followed the celebrated Phillips' decision, our Board has been reluctant to undertake an indiscriminate use of this apparent power. It would seem that the Board is empowered to set the prices of well head gas (including propane and butane) ${ }^{14}$ to be "used, consumed, stored or retained within Alberta", and perhaps for other gas as well.15

The apparent power to fix propane and butane prices is set forth in Section 6.1. This power is predicated on the fact that the propane and butane are produced within Alberta.

Thus the Board would not need to be dealing with "an owner of a gas utility" and hence a valid finding that the gas plant was a "gas utility" (either before or after the aforementioned declaration of the E.R.C.B.) would not be a condition precedent to any price fixing order. The writer is aware of only one instance where the Board has set a well head price for natural gas ${ }^{16}$ and in that case a bona fide gas utility was a party to the supply contracts but this was not the basis of the decision.

The Board proceeded in the Canadian Propane Hearing on the basis of its powers under Section 27 which clearly deals only with "an owner of a gas utility". It is worthy of note that Part $4^{17}$ is headed "Rates and Schedules" and commences with Section 26 which deals with the "Duties of an Owner".

Part 4 of the Act ${ }^{18}$ deals with "Miscellaneous" provisions including Franchises, Gas Contracts, Offences and the usual privative clause. ${ }^{19}$

It has been suggested that Section 40 would preclude the supplier of gas to an electrical utility from ceasing to supply at the end of a term of

\footnotetext{
"The Petroleum Administration Act. 1st Session, 30th Parliament, 23 Elizabeth 2, 1974.

12 See O'Connor J.A. at 392 of Ajax Alberta Pipeline Ltd. v. Canadian Chemical [1955] 2 D.L.R. 385. See also McAllister, Lord Hale and Business Affected with a Public Interest (1929) 43 Harvard L.R. 759.

i: Sections 6 to 12.

i" Section $6(1)$.

is Section 6(1)(a).

16 Madison Natural Gas Company Limited, Western Decalta Petroleum Ltd., Canadian Western Natural Gas Company Limited and the Valley Gas Company Limited Board Order No. 30972 where a price of 40.84 per mef was set for Turner Valley gas. See also decision No. C.75045.

1) Sections 26 to 37.

in Sections 38 to 54.

iv Section 54 excludes the judicial review of Board decisions by way of prohibition, injunction or certiorari.
} 
a contract. Quaere: Is this supplying gas indirectly to the public by way of electricity?

We are then driven back to Section 2(f) which defines a "gas utility". The words "whether an individual or a corporation" were inserted in Section 2(f)(ii) after the Ajax case; ${ }^{20}$ however, I would submit that this amendment only obviates part of that decision. The words "to or for the public or any member of the public" still must be read in the light of the comments of the Alberta Court of Appeal in the Ajax case. Where there is no franchise granted and no definable group of consumers who are by force of circumstance expected to deal with a supplier then the traditional rate base accounting principles which apply to a common law public utility are just not appropriate. Where consumers may resort to a number of suppliers to obtain the same product or service then it is hard to imagine how the "public interest" can be served by "regulation" of a competitive market place. If competition is not possible then there is no choice and regulation must follow. However, as has been found in the United States recently, regulation brings with it the added burden of costs which must ultimately be borne by the consumer if the product and service is to continue to be available.

Section 2(e) defines a "gas pipe line" to be "any pipe or any system" that is "wholly within the Province whereby gas is conveyed from any well head" etc. Section 2(f)(i) makes such a pipe line a "gas utility".

The Alberta Gas Trunk Line is apparently such a pipe line even though it has substantial interprovincial "connections". Similarly, absorption and scrubbing plants are also gas utilities pursuant to 2(f)(iii), but gas wells would appear to be only a gas utility if so declared by the Energy Resources Conservation Board (Section 2(f)(iv)). If these works are employed for the processing of gas whose ultimate consumption is by persons outside of Alberta, then the provincial public interest can only be protected at the expense of the extra-provincial public interest. ${ }^{21}$ Is this a valid basis for jurisdiction under Section 92 of the B.N.A. Act? The potential conflict with Bill 32, should it be passed by the Federal House, is rather obvious.

In the press release of March 7, 1974, the then Minister of Utilities and Telephones observed:

It is not proposed that the Lieutenant Governor in Council instruct the Board to fix prices at either wholesale or retail levels at the present time.

Nor is it proposed that The Public Utilities Board be requested to fully regulate the industry on a rate-of-return basis as is common for monopoly utility franchises. (i.e. propane and butane industry)

We will await with interest the revelation of what form that regulation will take, both as to propane distributors and gas producers and others.

20 Check the wording of the present section with that quoted in the Ajax case.

"Only 155 of propane produced in Alberta is consumed within Alberta. Most gas plants process gas that is destined exclusively for the extra-provincial market. 